\title{
A Retrospective of the First 3 Weeks of Infection with SARS-CoV-2 in Romania
}

Andrei MARIN', Liviu VASILESCU², Georgiana Gabriela MARIN³, Victorita Georgiana TUDOSIE4, Cristian BAICUS ${ }^{5}$

\begin{abstract}
The new Coronavirus (SARS-CoV2) represents a worldwide problem, with serious social, health and economic impact. Prevention and early implemented political measures resulted in a lower impact when referring to human casualties as well as socio-economic issues.

The following article comprises a 3 week retrospective of the Coronavirus outbreak in Romania, correlating the number of cases with the timeline of the political measures.

Keywords: new Coronavirus (SARS-CoV2), epidemiological investigation, political policies in Romania.

\section{Rezumat}

Noul Coronavirus (SARS-CoV-2) reprezintă o problemă mondială cu un serios impact social, medical și economic. Prevenția prin măsuri politice implementate timpuriu reprezintă soluția pentru ca această epidemie să aibă un impact minim din punct de vedere al numărului de victime, însă cu multiple consecințe socio-economice.

Articolul cuprinde rertrospectiva pe o perioadă de 3 săptămâni de la momentul apariției noului Coronavirus în România, corelând numărul de cazuri cu cronologia măsurilor politice implementate.
\end{abstract}

Cuvinte cheie: noul Coronavirus (SARS-CoV2), investigație epidemiologică, politici de sănătate publică în România.

\section{INTRODUCTION}

The novel Coronavirus (SARS-CoV-2) was first detected in China in December, 2019¹. Since then, there have been many cases reported worldwide. Information about treatment and the management of critically ill patients is still scarce. Therefore the evolution of the virus dissemination correlated with the political policies need to be reviewed via a retrospective observational study for the Romanian population in order to see how the social factors influence the number of infected patients.

\section{METHODS}

We analyzed in dynamics the data provided by the Johns Hopkins Coronavirus Resource Center and observed the numbers of patients in Romania for the first 3 weeks after the announcement of the first diagnosed case $^{2}$. In Romania, only the suspect patients were tested

\footnotetext{
1 Department of Plastic Surgery, „Bagdasar Arseni” Emergency Hospital, Bucharest, Romania

${ }^{2}$ Graphic Designer, LVDT, Bucharest, Romania

${ }^{3}$ Department of Cardiology, „Prof. Dr. CC Iliescu” Emergency Institute of Cardiovascular Diseases, Bucharest, Romania

${ }^{4}$ Department of Pediatric Psychiatry, „Al. Obregia” Hospital,

Bucharest, Romania

${ }^{5}$ Department of Internal Medicine, Colentina Hospital, Bucharest, Romania
}

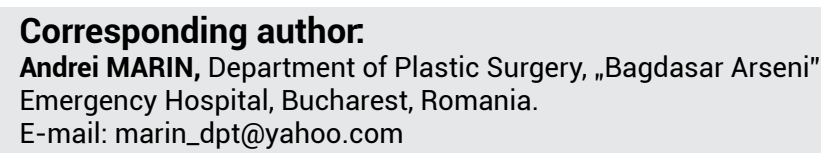


for COVID-19. These were patients with acute respiratory infection (experiencing one of these symptoms: cough, fever, sore throat, shortness of breath) and either contact with a patient infected with COVID-19 in the past 14 days or history of travelling in the past 14 days in one of the countries extensively affected by COVID-19.

We present the epidemiologic investigation for the spreading of the virus and we try to correlate these numbers to a series of factors: the restrictive measures recommended by the medical personnel or imposed by the government, number of contacts for each infected patient, degree of quarantine adherence, border restriction/permissions.

\section{Epidemiologic chain}

Italy, one of the most affected countries, declared its first cases on the $31^{\text {st }}$ of January. The first diagnosed case of COVID-19 in Romania occurred on $26^{\text {th }}$ of February in Gorj County in a rural area. Patient 0 was an Italian citizen who stayed in Romania for 5 days. In his case, the transmission was self-limited.

One key link in disseminating this virus was case number 17 - that of a man who falsely declared not having travelled abroad. In reality he returned from Israel on $26^{\text {th }}$ February. After being admitted on the $5^{\text {th }}$ of March into the hospital for another disease, he was found infected with coronavirus on the $9^{\text {th }}$ of March. Since his return into the country, the patient contacted over 150 people; over 15 people confirmed infected and an entire hospital in Bucharest was placed in quaranti$\mathrm{ne}^{3}$. Another similar case was that of woman in Hunedoara County, who also falsely declared not travelling in a country extensively affected by COVID-19 and then having contact with 42 people $^{4}$.

These false declarations postponed the epidemiologic investigation, thus increasing the risk of infecting more people.

As shown in the image below, the patients who did not respect self-isolation (either by lying about travelling abroad or by leaving the isolation) managed to infect a great deal of people who they have been in contact with.

\section{Local government and international measures}

In Romania, all meetings with more than 1000 people were forbidden starting $8^{\text {th }}$ of March; on the same day, the practical courses for medical students which took place in hospitals were suspended; the patients' relatives were no longer allowed to enter the hospitals' perimeter for visiting hours.

A restriction for gatherings/social activities with no more than 100 people went into effect on the $12^{\text {th }}$ of March and this number got reduced to 50 on the $14^{\text {th }}$ 6,7. Romania closed all schools on the $10^{\text {th }}$ of March and 2 days later the World Health Organization declared pandemia ${ }^{8,9}$. The Romanian president declared state of emergency starting $16^{\text {th }}$ of March, requesting citizens to stay indoors and to exit only for food and medicine.

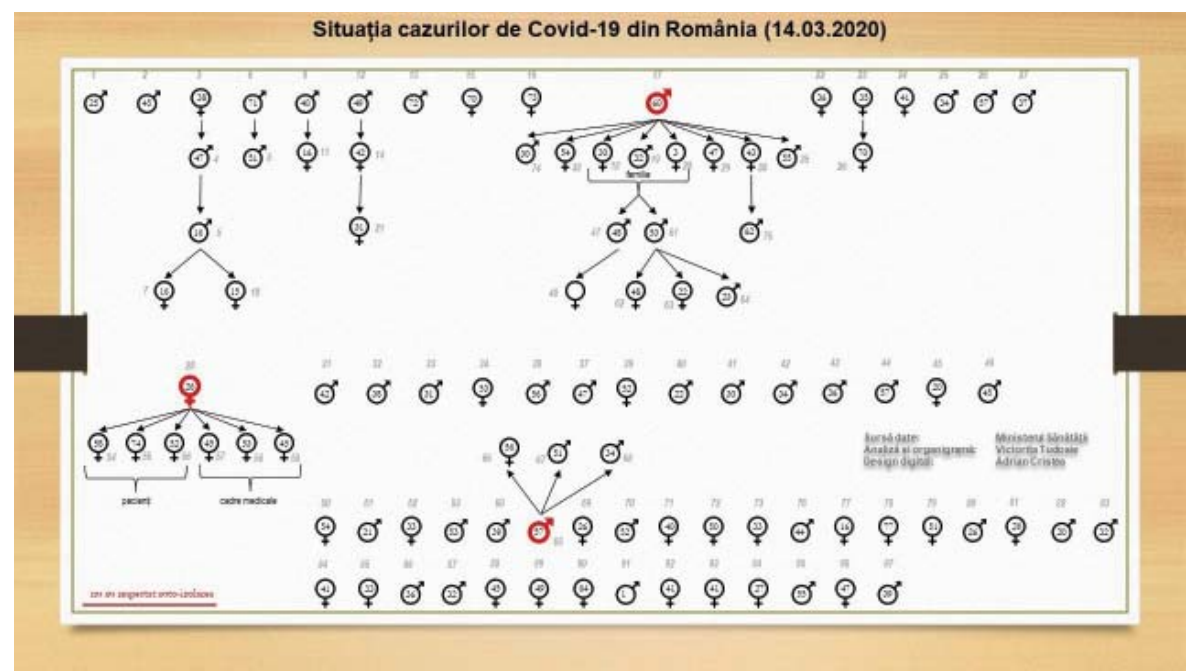

Figure 1. Transmission of COVID-195. 


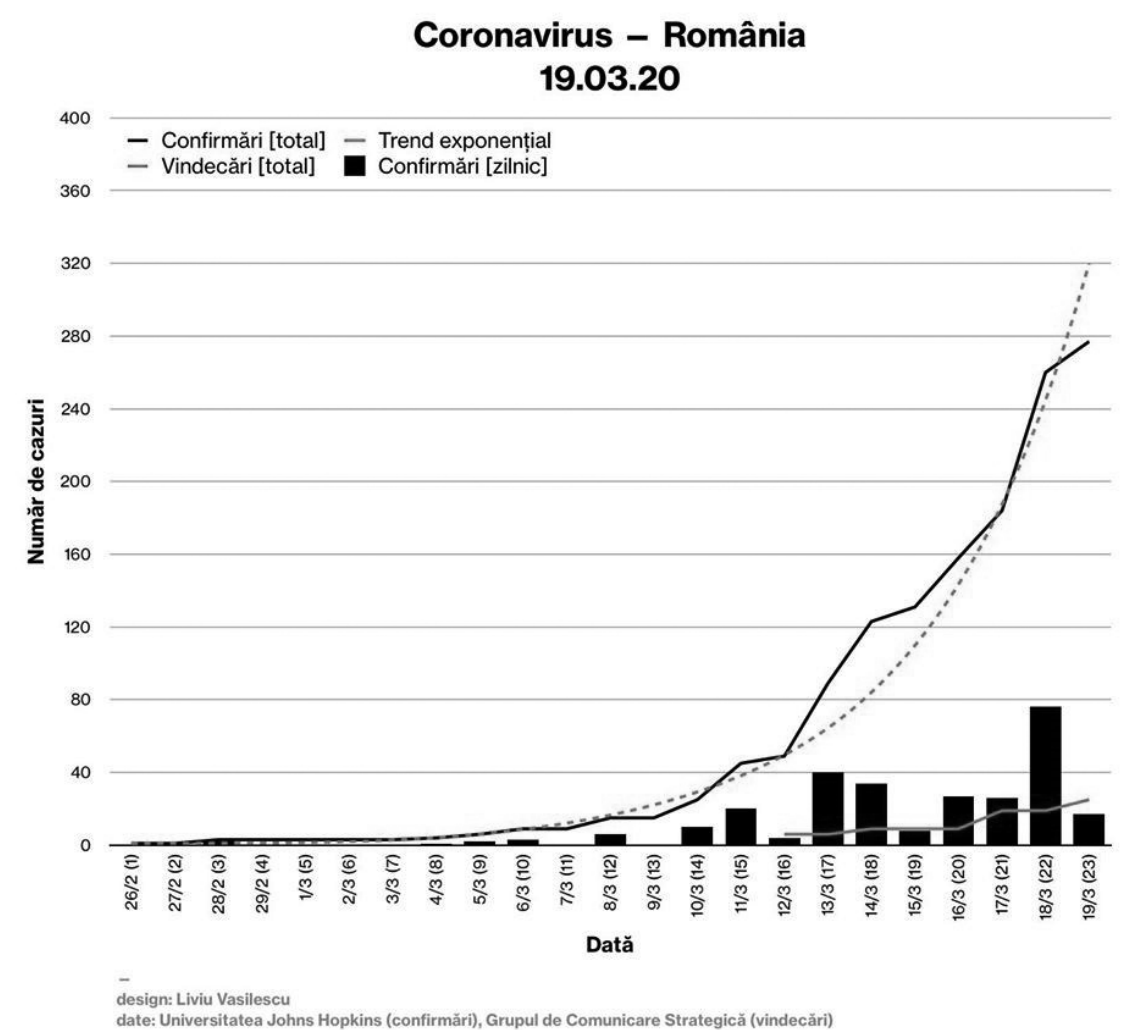

Figure 2. Coronavirus - România.

\section{RESULTS}

The chart on the evolution of this virus shows that there was an exponential growth in the number of new cases. Although precaution measures were taken by the government, the number of new cases rose.

On $19^{\text {th }}$ of March, there were no deaths reported in Romania. The new cases were either from abroad or patients who were in contact with the infected coming from abroad.

\section{DISCUSSIONS}

The number of new cases was probably the result of the patients who had already been infected, but weren't diagnosed. This is due to the fact that the number of diagnosed cases and the number of real cases was not the same, since not all patients with the specific symptoms were tested ${ }^{10}$.

On one hand, the restrictive measures restrictive measures taken showed their effect after a few weeks - they did not end the epidemics, but limited the exponential rise. The null fatality at the end of the $3^{\text {rd }}$ week was related to the fact that only a small number of patients (about 10\%) were over 60 years old ${ }^{11,12}$.
On the other hand, lack of proper protective equipment as well as specific circuit inside hospitals could cause intra hospital contamination, increasing the number of cases. Asymptomatic patients can be difficult to detect due to the testing possibilities and they can also become a cause of community transmission.

\section{CONCLUSIONS}

Social distancing and strong authority measures implemented early represented the key to reducing the incidence SARS-CoV-2. No community transmission was reported until the $3^{\text {rd }}$ week, as the epidemiologic investigation could trace all the infected patients.

A small number of new patients allowed the medical system to cope with the permanent flux of patients needing health care.

Compliance with ethics requirements: The authors declare no conflict of interest regarding this article. The authors declare that all the procedures and experiments of this study respect the ethical standards in the Helsinki Declaration of 1975, as revised in 2008(5), as well as the national law. Informed consent was obtained from all the patients included in the study. 
Andrei MARIN et al.

\section{References}

1. Isaac Ghinai*, Tristan D McPherson*, Jennifer C Hunter, Hannah L Kirking, Demian Christiansen, Kiran Joshi, Rachel Rubin, Shirley Morales-Estrada, Stephanie R Black, Massimo Pacilli, Marielle J Fricchione, Rashmi K Chugh, Kelly A Walblay, N Seema Ahmed, William C Stoecker, Nausheen F Hasan, Deborah P Burdsall, Heather E Reese, Megan Wallace, Chen Wang, Darcie Moeller, Jacqueline Korpics, Shannon A Novosad, Isaac Benowitz, Max W Jacobs, Vishal S Dasari, Megan T Patel, Judy Kauerauf, E Matt Charles, Ngozi O Ezike, Victoria Chu, Claire M Midgley, Melissa A Rolfes, Susan I Gerber, Xiaoyan Lu, Stephen Lindstrom, Jennifer R Verani, Jennifer E Layden, for the Illinois COVID-19 Investigation Team ${ }^{\dagger}$. First known person-to-person transmission of severe acute respiratory syndrome coronavirus 2 (SARS-CoV-2) in the USA. The Lancet March 13, 2020DOl:https://doi.org/10.1016/S0140-6736(20)30607-3

2. https://coronavirus.jhu.edu/map.html

3. https://www.hotnews.ro/stiri-coronavirus-23720648-cate-cazuri-confirmate-coronavirus-legatura-politistul-pensionar-care-mintit-doctorii-nu-fost-plecat-din-tara.htm

4. https://www.digi24.ro/stiri/femeia-din-hunedoara-depistatacu-coronavirus-si-care-nu-a-respectat-izolarea-are-dosarpenal-1274249

5. https://www.facebook.com/victorita.tudosie?_tn__=\%2CdCR-R\&eid=ARDg1 s0MFHOdhq01 TPJYOEMf9qhsZzOaca-
DEkYt4xY1kT3CambGMJkSZmaMCox29EYsrlyLSEXIZWOE\&hc_ref=ARTIg1p7yN9zu0qQfOnVqfg2kfynrOWiGxyEhRwKUD WCOJZ2qho_40lh_kMY8zAgUOQ\&fref=nf

6. https://www.infomusic.ro/2020/03/coronavirus-romania-activitati-cu-peste-100-de-persoane/

7. http://stiri.tvr.ro/se-restric--ioneaza-adunarile-publice-cupeste-50-de-persoane--noi-masuri-anun--ate-de-comitetul-na--ional-pentru-situa--ii-speciale-de-urgen--a_857640 html\#view

8. https://www.digi24.ro/stiri/actualitate/toate-scolile-din-romania-se-inchid-din-10-martie-pana-dupa-paste-1272588

9. http://www.euro.who.int/en/health-topics/health-emergencies/coronavirus-covid-19/news/news/2020/3/who-announces-covid-19-outbreak-a-pandemic

10. https://medium.com/@tomaspueyo/coronavirus-act-todayor-people-will-die-f4d3d9cd99ca

11. https://raportuldegarda.ro/articol/predictie-scenarii-varf-covid19-evolutie-romania/

12. https://app.powerbi.com/view?r=eyJrljoiNzczMDcxMWMtZ GFkNS00NTg4LTImMTItNGQzYThjYZZmMGNhliwidCI6ljg5Z JjM2U5LTKOMDUtNGQwNy1iZTMxLTc3YTgxOGYZOTU5MSJ 9\&fbclid=IwAR06DexFZtnWLXqsTD2IXTpQCdWvoz-hFNBttIOEXBU6vY8H72LEiqEMIfY 